\title{
Born to be Global: The YouCan Group Case*
}

\author{
Sara Roversi ${ }^{* *}$
}

\begin{abstract}
2003 was the year we decided to really get involved in the game. We were driven by the curiosity to understand the world and everything that revolves around it, transferring and enhancing it with an entrepreneurial approach in contexts that our company, You Can Group (founded by Sara Roversi and Andrea Magelli), has been exploring throughout these exploration years. Today, You Can Group is many things; an incubator for ideas and projects that has naturally evolved in an organic way and continues to evolve each day; a creative workshop in which format, events and concepts come to life with different characteristics and missions; an entrepreneurship workshop where participants can learn a trade and give birth to their own start-ups, thanks to a dependable network of seasoned individuals with years of experience, and the creation of know-how in constant evolution that encourages the mindset of sharing and growth. This is a family of companies with about 20 businesses and over two hundred employees
\end{abstract}

Keywords: Start-Up; Ecosystem; Born Global; Food Business; Global Markets

\section{The History}

Education, entrepreneurship, innovation and communication play a vital role in creating a better future for job creation, happiness and prosperity for all. You Can Group promotes and implements business projects in different sectors, taking advantage of the diversification of the group's companies to achieve real business projects in the field of food and digital communications. Bologna, the city we grew up in, was a natural choice for the company headquarters as it gave rise to and is continuing to develop our business venture, which is a socio-economic ecosystem mainly active in the food, digital and design sectors, and social innovation and creative learning.

The first project that we launched was Lifeinaclick, a digital company that specializes in emotional marketing services primarily active in major events such as concerts, road shows and international events such as the Olympic Games. In 2005, after only two years of business, our travels and curiosity met the design world, ushering in a long-standing and exclusive partnership with the Canadian company

\footnotetext{
* Invited Article

** Founder, YouCan Group (sara.roversi@youcangroup.it)
}

Roversi, S. (2015). Born to be Global: The YouCan Group Case, Symphonya. Emerging Issues in Management (symphonya.unimib.it), 3, 71-77. 
Molo Design. Molo Design is a unique furniture company that makes distinctive and practical furniture as well as dividers and lighting fixtures entirely out of paper with an innovative approach that is creative and entirely sustainable. We have always maintained a balanced attentiveness for all our projects, including those that we keep on the back burner, and follow our passions, which, as a result, led us on the path of emotional marketing and overseas design. Our road has now taken a new and even more thrilling direction: the world of food.

Thus, the dawn of a new era commenced for You Can Group and with it, the birth of various food formats such as Sosushi, which in 2005 was able to bring the cuisine of the Land of the Rising Sun into the historic centre of Bologna, reaching 35 stores in 2011 and then sold to a British fund. To follow Sosushi was WellDone, more than just a high quality burger joint, it has become a local hot spot that has redefined the gourmet burger experience. WellDone offers a new way to eat and enjoy the classic sandwich with quality and local ingredients offered to customers in unique combinations. All locations are furnished with an elegant, vintage chic style, refurbished with one-of-a-kind pieces mixed and matched with original design elements and a unique touch; a treat for the eye as well as the palate. This is how these successful projects came to life, bringing the latest trends in gastronomy from all over the world to Italy. At the same time, we were able to become international ambassadors of Italian culinary excellence, particularly the culinary excellence of the city of Bologna. We first landed in the cosmopolitan city of San Francisco where we decided to open the first Tortellino Gourmet Pasta to Go location outside Bologna. Tortellino is based on the format of the acclaimed Bolognese pasta tradition, which we were able to introduce to the international street food scene.

We were able to manage to combine historical gastronomic tradition of our home town with street food culture. Tortellini, tagliatelle, ravioli and other succulent Emilian pasta specialties served in convenient packaging that allow people to enjoy a tasty and authentic Bolognese meal on the go, anytime. Preserving Italian food traditions, which are often precursors for future food innovations, has also convinced us to invest in projects that have been started by likeminded dreamers, such as 'O Fiore Mio, gourmet pizzeria born in Faenza, and I Love Italian Food, an international network dedicated to promoting Italian food throughout the world.

Travelling and establishing international relations has been key for You Can Group and we pride ourselves on being a youthful, dynamic team constantly evolving and growing. We are immersed in a competitive global environment, living in a prosperous territory that is very much rooted in its traditions and we are fuelled by the will to bring positive stimuli and cross-pollination into the community that welcomes us and make it attractive for young talent. These are just some the ingredients that have guided us throughout the years and we have devoted vast resources and energy into projects to advance the ecosystem, forming our team in an unconventional way, stimulating the creation of new businesses, sharing best practices, initiating open innovation paths and co-designing and generating positive impacts on the world around us.

It has taken several years for us to strike the perfect balance and channel our entrepreneurial spirit towards a new dimension where education, entrepreneurship and innovation intersect. Apprenticeships, internships, hackathons and project 
works carried out in partnership with international business schools and start-up meetups, our Global Trep Training Program are just some of the activities promoted by the group, but food remains the predominant theme.

\section{The Vision}

Why food? Food is of prime importance. Food is a global language and a highly interdisciplinary field, it is the first commodity and primary form of cultural expression that unites people, industries and countries. Finally, food actors are and should be the pioneers in taking care of something more than just profit because their choices can have strong impacts on health, economic growth and sustainability for the planet.

That is why in 2013 we brought to life an even bigger and ambitious project, rooted in the heart of the Italian Food Valley, the non-profit organization, Future Food Institute. Acting as Trustees are Prof. Matteo Vignoli, expert in Design Thinking and processes of innovation, and 'policy shaker', Alessandro Pirani. In addition, the Future Food Institute is joined by knowledge partners and international supporters such as the Institute for the Future (IFTF) in Palo Alto, USA, which is also a non-profit with over 45 years of dedicated work and research into the trends and study of future scenarios, and the Google Food Innovation Lab team.

Through the Future Food Institute, our mission is to nurture a new generation of visionaries that aspire to become food entrepreneurs and managers, we bring together innovation and expertise to local companies and generate positive effects on the local community; our mantra is "Innovation is a cooperative effort." These simple yet strong words strengthen the aims of the Future Food Institute, the Faculty of Engineering of the University of Modena and Reggio Emilia and Institute for the Future and bring together public administration, big companies, small entrepreneurs, cooperatives, industry associations, private individuals, activists, great thinkers, researchers, Michelin-starred chefs, students, teachers, children and ordinary citizens.

$\square$ In 2015, from this ambitious project, the Food Innovation Program (FIP) was born, a full-time master's program focused on the food sector, innovation and entrepreneurship in order to address the future needs of the global food networks and industries. The first edition of FIP had 20 students from 11 countries from all over the world who all were unique and came from different backgrounds, but who all had one passion in common, the desire to become positive and effective actors of change in the food industry.

More specifically, the Food Innovation Program aims to identify new technologies for agriculture, food distribution, retail and consumer, taking into account food security, social relations and regulations, advocating the dissemination of best practices and generating radical innovations in the food industry. Keeping in line with the "Seeds of Disruptions" forecast map created by 
the Institute for the Future that conveys how emerging technologies can be used to close important gaps in the food system, the Food Innovation Program also incorporates the Reggio Approach (an educational teaching approach that recognizes and cultivates creativity and interest in learning). FIP is a fertile and stimulating environment that successfully combines Design Thinking and Foresight - fuelled by an outstanding faculty from the University of Modena and Reggio Emilia and other partnering international institutions. It is a creative powerhouse that offers theoretical lectures, practical exercises and experimentation that allows students to go against the grain and challenge current paradigms in the food industry, contribute to innovation and build a positive feedback loop to society. As part of the rich and vast learning experience, the Program had an important and unique aspect, the OffiCucina, a hybrid kitchen maker-space with state of the art equipment such as lasers and 3D printers and traditional tools for students to experiment, create and share ideas. It is a unique space that thrives on the collaboration of a large group of influential actors that provide non-financial based resources to young entrepreneurs. It is worth noting that in Italy alone, there are over 60 co-working spaces across the nation, 46 FabLabs, 21 organized hackathons, 48 calls and 38 empowerment programs, and hopefully these will continue to flourish as their value to society become ever more evident.

Going back to FIP, the first edition of the Program and the entire network of related activities (hackathons, conferences, public events, 25 workshops open to schools and children, field trips and project works, etc.) have led to real business projects, collaborations with large international companies and figures and has helped expand our network to over 350 food start-ups active in the market today. In addition, it has created over 50 prototypes of new products or new services, some of which have also been adopted by partner companies, as well as creating six research projects developed today within our Fellowship Program, involving more than 30 companies and thousands of people who have made contact at least once with our students. Indeed, it has been an impressive year for the Food Innovation Program; from a first prototype, it has truly evolved into a real training platform.

\section{$\square$ The second edition of the Food Innovation Program is already in the works and will start in September 2016. It was a 12-month experience that will be even more "global" with a Food Innovation World Tour that will bring students from Reggio Emilia to Silicon Valley and Shanghai.}

In addition, we will be launching a Food Innovation Executive Program designed exclusively for managers of food companies and also a Mediterranean Summer School program that will take place on the enchanting island of Sicily in July 2016. All these programs will take place alongside various laboratories geared towards children and teens curious to learn and understand how to make positive impacts on their local communities and become champions in-training who will one day safeguard the future of food.

But through it all, we never forget our roots; we are entrepreneurs and, thanks to the vast array of impetuses and unforgettable experiences lived through during the Food Innovation Program, we continue to advance the You Can Group mission - 
"Entrepreneurship and Innovation for Growth" - along with the issues supported by the Future Food Institute, we have teamed up with Tree Srl. (a leading Sicilian company in consulting on open innovation and tutoring for start-ups) to give life to the Future Food Accelerator. The goal is to offer the most innovative companies in the food chain a customized path by involving experts that guide them to large companies, or introduce them to potential investors. To date, the Italian ecosystem has led to 5,182 innovative start-ups, most of which are located in the regions of Lombardy (1142) and Emilia Romagna (579). However, there are only 40, of those with more than 500,000 Euros in capital, while the majority fall between 1,000 to 5, 000 Euros. In addition, the majority of these $(5,095)$, do not exceed 9 employees. When taking into consideration the investment scene, be it institutional investments, venture capitalists or angel investors, these are also singular cases at best. It is worth noting that in 2015, 133 million Euros for start-up investments in Italy was provided, however, when compared on the European platform, this is a figure that corresponds to only a tenth of what is invested in start-ups in France and Germany, and half of what is invested in Spain. It is precisely for this possibility basin that we decided to create the Future Food Accelerator.

A joint effort that takes advantage of our already established network, expanding the food community.

Many of us look within our country for inspiration, but often times the inspiration comes to us from looking beyond our own backyard. In our case, we often look to Silicon Valley. For us, it is the land of innovation, technology and cutting edge visions and also the place to meet exciting people and cross pollinate ideas. It would be here where we would have met two of our members, now an integral part of our ecosystem: Alessio D'Antino and Pierluigi Santoro.

Two talented young Italian entrepreneurs, united by the desire to give form and substance to their projects. Alessio, a native of Turin, is the quintessential global citizen, an expert in food and finance, and the creator and founder of Crowdfooding, an equity crowdfunding platform for food start-up, based in UK.

$\square$ While in Italy there are 55 crowdfunding platforms that are $100 \%$ Italian: 20 Reward-based, 14 Equity-based, 6 Donation-based, 2 Lending-based and 13 that care categorized as hybrid (combination). It is interesting to point of that Italy was the first country in Europe to adopt a Regulation on Equity Based Crowdfunding with the Growth Decree 2.0, Decreto Crescita 2.0 (Decree Law 179 of October 18, 2012) and Resolution no. 18592 of CONSOB (Commissione Nazionale per le Società e la Borsa, which is the public authority responsible for regulating the Italian financial markets).

The projects received from the Italian platforms are more than 50 thousand, of which about one third are published and among them about $35 \%$ are actually financed.

Fundamentally, Crowdfooding is an element that enriches our world by providing opportunities for alternative fundraising for start-ups and much more. Then there is Pierluigi Puglia, gifted agronomist educated in Wageningen. Like us, he is a serial entrepreneur and because of him we were able to realize one of our greatest dreams: 
to return to the land, the Italian countryside and reconnect with the world of agriculture. With us and specifically with Alessandro Roversi (You Can Group partner), we founded Future Farm, our first experimental and innovative farm prototype. There are two production chains that will be carried out, one derived from organic agriculture aimed at the production of low-gluten flour made from ancient grains and the other being the recycling and reuse of agricultural waste. Keeping the imprinting of the mother project, ample space will also be allocated to an authentic recreational area that will be equipped to host students, researchers and Agtech start-ups in need of hands-on field practice for testing and prototyping. This was a valid and sound choice, given the data recorded on start-ups in the post Expo backdrop where, at least thematically, the majority remained in the combination of agritech-sustainability comprised of $32 \%$ of registered enterprises in processing, which is a much more massive share than the sharing economy (20\%), e-commerce and distribution (12\%), safety and traceability, and health (both $11 \%$, respectively), superfoods $(9 \%)$ and retail $(5 \%)$.

\section{Conclusion}

There have been countless brilliant minds and start-ups that we have had the privilege to meet throughout the years and who we can proudly add to the growing network of You Can Group and the Future Food Ecosystem. Some of them have become true champions within the group and have enriched the skills and services the entire system, others have entered the family and have opened up new lines of business, but the vast majority have been true agents of change within the entire industry and have brought innovation to the industry, turning into companies or have evolved into new projects within consolidated companies.

Thanks to all the vibrant facets of the start-up world, we have been able to continuously evolve and define our mission, always remaining true to the principles of encouraging the birth and growth of young entrepreneurs and food innovators who are responsible visionaries who are able to generate a positive impact on society. We had a dream of bettering the world for our children and so we set out to make this dream come true, one day at a time, making our contribution and always remembering to never stop dreaming.

\section{Bibliography}

Arora, A., \& Gambardella, A. (1994). The changing technology of technological change: general and abstract knowledge and the division of innovative labour. Research Policy, 23(5), 523-532. http://dx.doi.org/10.1016/0048-7333(94)01003-X

Arrigo, E. (2009). Market-Driven Management, Global Competition and Corporate Responsibility, Symphonya. Emerging Issues in Management (symphonya.unimib.it), 1, 54-70 http://dx.doi.org/10.4468/2009.1.06arrigo

Blank, S. (2013). Why the lean start-up changes everything. Harvard business review, 91(5), 63-72.

Brondoni, S.M. (2010). Intangibles, Global Networks \& Corporate Social Responsibility, Symphonya. Emerging Issues in Management (symphonya.unimib.it), 2, 6-24 http://dx.doi.org/10.4468/2010.2.02brondoni 
Brondoni, S.M. (2015). Global Networks, Outside-In Capabilities and Smart Innovation, Symphonya. Emerging Issues in Management (symphonya.unimib.it), 1, 6-21 http://dx.doi.org/10.4468/2015.1.02brondoni

Criaco, G., Minola, T., Migliorini, P., \& Serarols-Tarrés, C. (2014). "To have and have not": founders' human capital and university start-up survival. The Journal of Technology Transfer, 39(4), 567-593.

Honjo, Y., Kato, M., \& Okamuro, H. (2014). R\&D investment of start-up firms: does founders' human capital matter?. Small Business Economics, 42(2), 207-220.

Lubberink, R., Blok, V., van Ophem, J. A., \& Omta, S. O. (2015). 11 The impact of domestic drivers and barriers on the entrepreneurial start-up decision. Family Entrepreneurship: Rethinking the Research Agenda, 239.

Mosca, F., Tamborrini, P., Casalegno, C. (2015). Systemic Design: How to Compete by Leveraging the Value System, Symphonya. Emerging Issues in Management (symphonya.unimib.it), 2, 42-56 http://dx.doi.org/10.4468/2015.2.04mosca.tamborrini.casalegno

Neubauer, F., \& Lank, A. G. (2016). The family business: Its governance for sustainability. Springer.

Tresca, R. (2013). Global Business Networks and the Competitiveness of SMEs, Symphonya. $\begin{array}{lllll}\text { Emerging Issues in Management (symphonya.unimib.it), 2, } & \text { 67-78 }\end{array}$ http://dx.doi.org/10.4468/2013.2.05tresca 